【論文】

\title{
A STUDY ON PSYCHOLOGICAL MAPS OF FIVE FORMER JAPANESE CASTLE TOWNS IN TERMS OF TOPOPHILIA
}

\author{
心理学的地図による五つの旧城下町のトポフィリアに関する研究
}

\author{
Agus Budi Purnomo ISHAK*, Tadahiko HIGUCHI** and Hidenori TAMAGA WA*** \\ アグスブディプルノモ イサク，樋口忠彦，玉川英則
}

\begin{abstract}
This paper attempts to form the psychological maps of five former Japanese castle towns along the Japan Sea coast by using topophilic dimensions. The cities being studied are Shibata, Murakami, Joetsu, Nagaoka and Toyama. The psychological maps were formed and analyzed by using principal component analysis and locational methods. As a conclusion :

1. Instead of a single construct of topophilia, two constructs which identify with direct and indirect contact sources of cognitive knowledge were extracted.

2. The indirect contact component identifies with historical and symbolic places, while the direct contact component identifies with commercial places.

3. The locational analysis indicates that both types of places locationally are not segregated.

Keywords : topophilia, psychological map, locational data, quantitative data, ecological analysis, environmental attitudes

トポフィリア，心理学的地図，場所データ，計量データ，生態学的分析，環境への態 度
\end{abstract}

\section{Introduction}

To develop a city so that it can be appreciated by its inhabitants will be easy.if we have the knowledge of what and where in the city are the places that are loved by, hated by, or unknown to the inhabitants. By that knowledge we could correctly enhance the quality of loved places, change hated places to loved places, and bring out unknown places to existence. Without it, we would change loved places to hated places, or turn well known places to oblivion (Jencks ${ }^{1)}, 1976$, Hester ${ }^{2}$, 1981).

To understand a person's environmental preference we need to examine his biological heritage, upbringing, education, job, and physical surroundings. Since topophilia is described by $\mathrm{Tuan}^{31}$ as all human affective ties to the environment, it can be considered as a synthesis of all factors which influence the environmental preference of a person. This paper is an effort to understand topophilia in five former Japanese castle towns.

Attitude is primarily a cultural stance, a position one takes in relation to the world. It is formed by a long succession of perception and has greater stability than perception ( Tuan $^{4)}, 1974$, Lang ${ }^{5)}, 1988$ ). Thus, instead of using perception like other researchers (Appleyard ${ }^{6}, 1969$, Evans et al. ${ }^{7}$ 1982), we will study topophilia in terms of environmental attitudes that were represented by several topophilic factors. Unfortunately in his book about topophilia Tuan ${ }^{8)}$ (1974) omits the research methods and other technical discussion on procedure. His main objective is to structure the theme of topophilia with a set of concepts. In this paper as a complement to Tuan's efforts in structuring the concepts of topophilia we

* Graduate Student, Science and Technology of Niigata Univer- 新潟大学大学院自然科学研究科 大学院生.工修 sity, M. Eng.

** Prof., Faculty of Engineering of Niigata University, Dr. Eng. 新潟大学工学部 教授.工博

*** Assoc. Prof., Faculty of Engineering of Niigata University, 新潟大学工学部 助教授・工博 Dr. Eng. 
will try to synthesize those topophilic concepts with systematic research methods. The method we used to synthesize those topophilic concepts is in a way similar to the method that was used by Gould and White' (1974) to synthesize the environmental preferences of their respondents. However unlike Gould and White ${ }^{10)}$ (1974) we will look carefully at the sources of environmental cognition mentioned by Milgram et al. ${ }^{111}$ (1972). Since the main purpose of Milgram's' ${ }^{12)}$ (1972) paper is not to describe the type of sources of environmental cognition, his paper did not discuss thoroughly those sources. Thus unlike Milgram's paper ${ }^{13)}$ (1974), along with the synthesis of Tuan's topophilic concepts ${ }^{14)}$, the classification of those synthesis in terms of the sources of environmental cognition will be one of the main objectives of this paper.

Usually environmental researchers entrust repetitions of their study to others. However by studying five cities we will consider the similar phenomena that may exist in the psychological maps of the five cities.

In other fields of studies (geography, etc. ) the analytical methods that were usually used to analyze a map are locational statistics. The methods were seldom or never used in the analysis of psychological map. Therefore this paper will try to analyze the psychological map in terms of its spatial and non-spatial aspects by using spatial and non spatial methods.

\section{Method}

\subsection{Variables of The Psychological Maps}

The variables we used to form the psychological maps were collected by using questionnaires. Instead of basing the questionnaires in terms of mere visual clues like most cognitive researchers, we used five topophilic variables that were mentioned by Tuan ${ }^{151}$ (1974). According to Tuan familiarity to a place can breed topophilia to the place by people ${ }^{16)}$. Therefore our first question ask the respondents about the names of places they consider as familiar. The second question asks the respondents about the names of places that were considered by them as beautiful. This question were based on Tuan's argument ${ }^{177}$ that visual appreciation of beauty is one of the basis of topophilia in certain places.

The third question is about the name of places that the respondents consider as to be protected. It is based on a type of patriotism which according to Tuan is not only a love for general places such as one's country, but a love for one's intimate places or things. Patriotism of this type which he argues is one of the factors that have the ability to evoke topophilia in certain places ${ }^{18)}$.

The fourth and fifth questions were based on Tuan's argument that topophilic feeling can also be evoked by frequent direct exposure to places ${ }^{19}$. Therefore the fourth question asks the respondents about the name of places where they usually conduct their daily life. The fifth question asks the respondents about the routes they usually take when going from their residence to their daily places, and about the places they usually pass as they travel the routes. Except for the fifth question, all other questions were conducted verbally. The fifth question uses map as a clue. On the map the respondents were asked to trace the route and mark the place in question with arrow. The map is standard road map with scales ranging form $1: 20000$ to $1: 15000$.

\subsection{Quantitative Data Formation}

Except for the fifth question, the other questions can be quantified into variable score of a place by using the number of respondents that chose to write the name of the place as their answer to the questions number 1 to 4 . For example, if 100 respondents in a city consider that place $A$ is beautiful by writing the name of that place on the answer section of question no. 2 of the questionnaire that were presented to them, then the variable no. 2 score of place $A$ is 100 .

The variable score of a place in term of the fifth question is determined by the number of respondents who correctly marked the location of the places that were asked on the question. For tolerance, a place is considered as correctly marked if it is within the circle of radius $125 \mathrm{~m}$ whose center is the point of arrow marked by the respondents to indicate the place that were asked for them to identify in the 


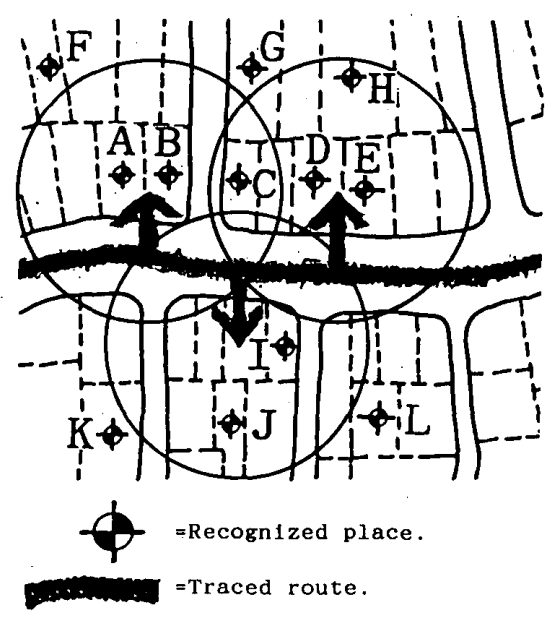

Figure 1 The score of places A, B, $\mathrm{C}, \mathrm{D}, \mathrm{E}, \mathrm{H}, \mathrm{I}, \mathrm{J}$ are counted, while of places $F, G, K, L$ are not counted. Place $\mathrm{C}$ is counted only once. All of the places with label are mentioned by the respondent on the questionnaire.
Table 1 Example of data matrix (a part of Murakami city's data matrix) as an input for principal component analysis. The unit of the scores is people.

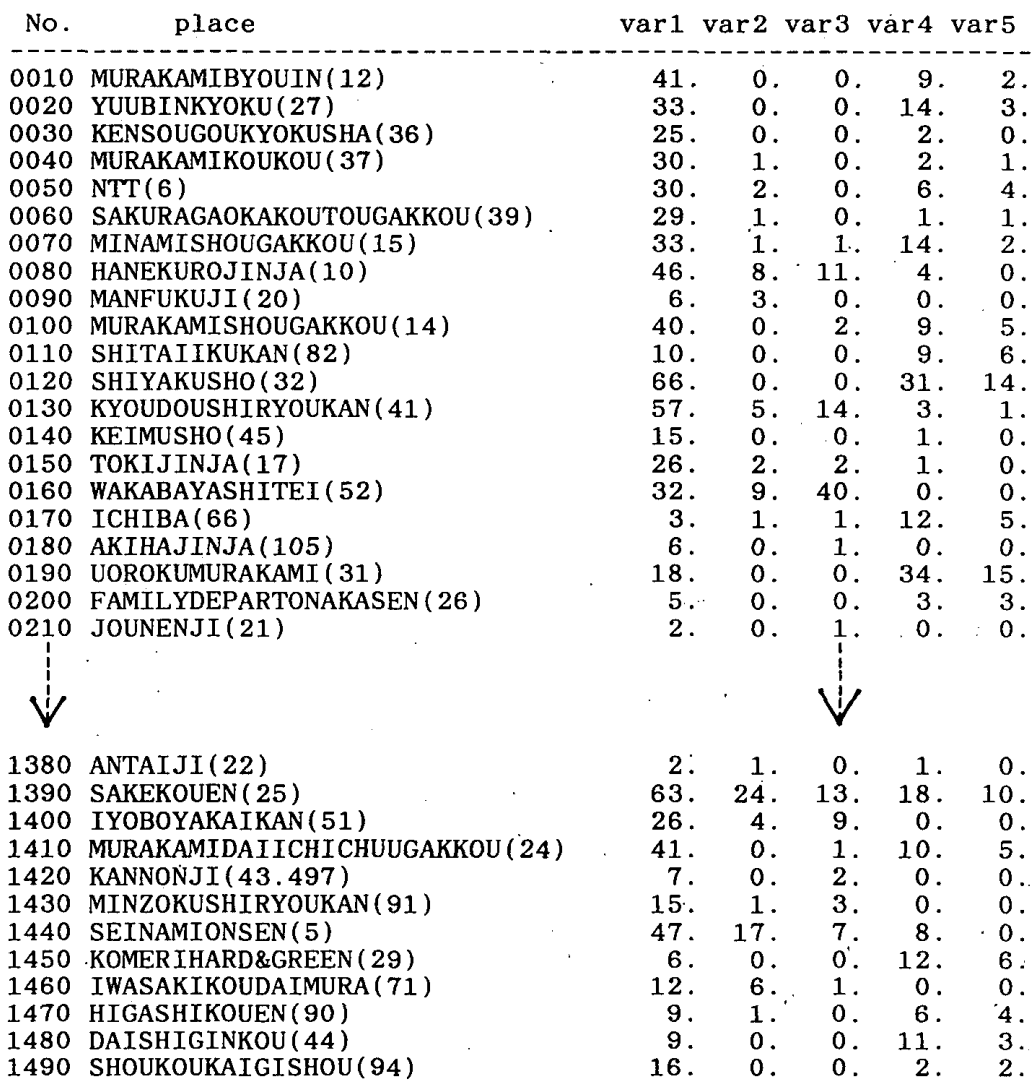

question (see Figure 1). The 125 meter radius of tolerance is determined by the fact that the average size of city blocks in our study is 125 by 125 square meter (Agus ${ }^{20)}, 1987$, Higuchi et al. ${ }^{21)}, 1988$ ). An example of data matrix of quantitative data can be seen on table 1.

\section{3 Locational Data Formation}

In terms of the location of a place on a map, we can consider the place as a point. Thus its coordinate can be determined. In this study we consider that the coordinate of each point as the coordinate of the centroid of land plot where the place exists. The shape of the plot were assessed from Housing Map with average scale of $1: 1700$.

\section{4 Ecological Data}

In ecological analysis we will use machi as our unit of aggregation. The average area of the machis is $1.00 \mathrm{~km} 2$.

\subsection{Study Area}

The study area is the densely inhabited district (DID) of each city and some of its non-DID surrounding.

The average area of the study area is $34.7 \mathrm{~km} \mathrm{2}$. The populations of the cities in the study are Toyama (184 872), Nagaoka (109526), Joetsu (71880), Murakami (18634), and Shibata (38 877), in 1985 DID.

\subsection{The Respondents}

From each of the five cities 380 respondents were chosen. They are the parents of fifth or sixth grades students of five elementary schools in each city. From each of the five schools in each city, the parents of 75 students were decided to be our respondents. From each of the five schools in each city the minimum number of respondents who complete usable questionnaires is only thirty. Therefore we only use 150 respondents out of the 380 respondents that were initially designated in each city. The average 
Table 2 The profile in terms of age and sex of the

Table 3 The profile of the term of residence of the respondents that were sampled in each city.

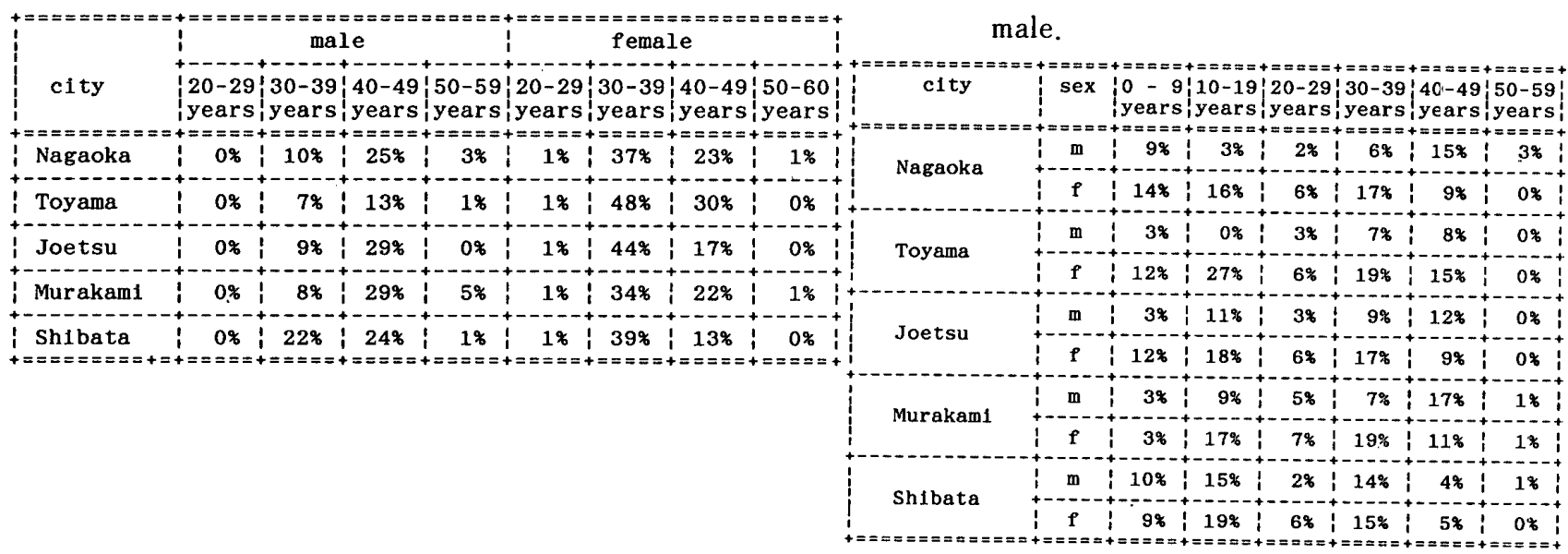

age of the respondents is 39.5 years. It ranges from 29 to 56 years of age. The proportion of female to male is 1.2. The average time of the respondents living in their city is 20 years, which ranges from 0.33 to 56 years. The distribution of the respondents in terms of age, sex, and the terms they have spent living in each city can be seen on table 2 and 3. Even though sex, age and the term of residence of the respondents in their city vary, from the data we can see that they do not influence the response of the respondents to the questions in the questionnaires.

The questionnaires were distributed to the respondents in each cities in the end of the first academic terms of 1987 and 1988. The distribution of the questionnaires were done through the schools of the respondents' children. The location of the schools are scattered within the area of each city. Therefore in terms of elementary school zone that were adopted in Japan, the scattered location of the schools can be used to ascertain a nearly random distribution of respondents' residential locations within each city in our study.

\section{Result and Discussion}

The two types of data mentioned on previous section deserve a separate analysis. The first part of this section will describe and discuss the result of the analysis of quantitative data that were formed by the method that were described at 2.3. The second part of this section will describe and discuss the result of the analysis of locational data that were formed by the method described at section 2.4. In the last part of this section, we will describe and discuss the combined analysis of quantitative and locational data analysis.

\subsection{The Result of Quantitative Data Analysis}

The quantitative data were analyzed by using principal component analysis. Similar to the objective of Gould and White ${ }^{22)}$ (1974), the main intention of using principal component analysis is to synthesize several concepts into a construct. In this study those concepts are the five topophilic variables, and the construct is topophilia. The result of principal component analysis can be seen from the two components abstracted from the five variables used in our study. Table 4 shows that the first component is explained mostly by variable number 2 and 3 where the former is the score of places considered as beautiful and the latter is the score of places considered as in need to be protected. Table 4 also shows that the second component in mostly explained by variables number 4 and 5 where the former is the score of places that are considered as frequently visited, and the latter is the score of places that are close to the respondents' frequented routes. Variable 1 which indicate the familiarity of places to our respondents almost equivalently explain both components.

It can be argued that the separation of the variables into two components is due to the choice of variables which were used in the study. Therefore if other variables were introduced, the result might be 
Table 4 Component loading of principal component analysis of quantitative data of cities in the study.

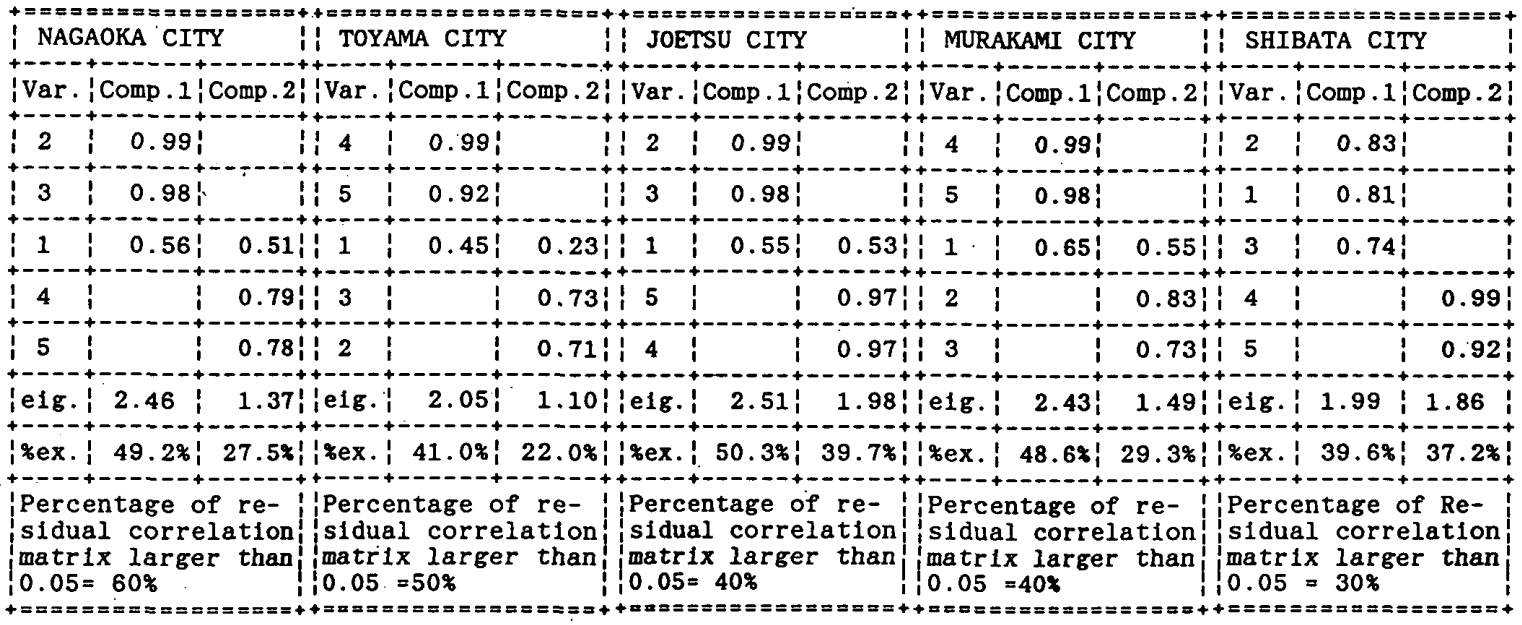

different. But since the respondents are open to the possibility of choosing or recognizing the place that have the characteristics of both components (e.g. place which is not only beautiful but also being visited frequently), this separation of variable into two components still shows the appropriateness of the variables used in this study. To explain this separation, let us answer the question of how the respondents in our study could considered a place as beautiful and needed to be conserved while they have seldom or never visited the place.

To answer this question, let us turn to Milgram's notion about direct and indirect source of environmental cognition (Milgram $\left.{ }^{23)}, 1976\right)$. For the five cities in the study, places that are considered by the respondents as beautiful and needed to be protected is dominated by symbolic and historical place such as castle remains and prefectural or municipal offices. The examples of such places are Shibata's Shimizu park, Joetsu's Takada park, Murakami's Kagyu mountain and Toyama's Joshi park. All contains the remnants of castle town past such as old castle wall or the garden of the former feudal lord. Symbolical and historical places, whether it is in order to enhance its dignity or does not function for daily human activities, often denied the respondents of direct contact experience. Thus it does not seem to be frequented by the respondents. Nevertheless such places in the five cities in our study are recognized by the respondents as strong as commercial places and places for daily human activities. Therefore the respondents must have learnt the existence of the place indirectly from other sources of knowledge such as books, atlases, even government pamphlets explaining their policy about the place.

On the other hand, the place that were considered as frequently visited by the respondents are dominated by commercial places for daily activities. Such places provide the respondents the daily direct contact to places. It gives the respondents a frequent first hand experience to a place. Even how unstimulating such a place at a glance, the frequency of direct contact will give the respondents a chance to develop a sense of place to it, so that it can imprint itself on the respondents cognitive vocabulary. The fact that such place is often a place where the respondent attend recreative activities such as gymnasium and pachinco parlor, further increase its probability of being imprinted into the respondents mind. The examples of such places are, Shibata's Daiei, Murakami's Jusco, Joetsu's Nagasakiya, Nagaoka's Daiwa and Toyama's Seibu. These places are all department stores. Therefore such places can be considered as the source of direct environmental cognition which are being denied by symbolic and historical places. For ease of saying, therefore we will name the two components as "direct component" for the component dominated by commercial and daily places, and for historical and symbolical places we will name it as "indirect component". These two components can be considered as to represent two types of topophilic concepts. The direct component represents topophilic sentiment to direct sources of environmental cognition and the in-direct component represents topophilic sentiment to the in-direct sources of environmental cognition. 
As a discussion, this dualistic view about one's city is prominence due to the type of cities we chose to study. The five cities being studied are former castle towns. Each has a significantly rooted historical background. All the five cities have strong symbolical and historical places remains of its castle town past. Along with commercial and daily places, it made a dualistic imprint to its inhabitant's cognitive vocabulary. For other types of city, which does not have historical remains, it must rely on the more functional products of modern culture as its symbol. To a certain degree, this effect of modernity can be seen in Nagaoka. In that city due to the rebellious event in the pre-Meiji era and the bombing of the second world war, contains relatively small number of historical remains which can evoke its castle town image. Therefore for symbolic element of the city most of our respondents turn themselves to Yukyusan parks where modern replica of a castle exists. Since the park also function as a place for recreation and sports, it has a strong score for both direct and indirect component. As such modification develops intensively all over the city, if similar method which were used in the present study are used to the city, the separation of the variables into two components might be less suitable. As we can see in table 4, from the reproduced correlation matrix, Nagaoka has the largest percentage of error that are above 0.05 . Which means the two component solution is relatively less suitable for Nagaoka.

Usually the more a city develops, the less will the number of symbolic and historical places being conserved. In exchange of such places, modern functional places were built. The symbolic function of the old places might and might not be inherited by the new places. Even if in someway the symbolic characteristics is inherited by the new places, since modern places tend to be functional, that characteristics may be complemented by frequency of usage. On the other hand, if the symbolic characteristics is not inherited by the new buildings, the cities' inhabitants will be gradually oblivious of the existence of the places. Both ways, it will produce a different structure than the two components structure in this study. This tendency can be seen from the increase of percentage of error in the reproduced correlation matrix (table 4), as the city being studied increase in terms of its size and developments. Finally as a conclusion of quantitative data analysis, it can be assumed that the dual components that emerge in this study are the characteristics of city with historical heritage such as the five former castle towns in our study.

\subsection{Result and Discussion of Locational Data Analysis}

The main intention of locational data analysis is to investigate whether the dual components solution of quantitative data can also be seen spatially.

The places that were recalled by our respondents can be classified as direct contact places (place type 1) and in-direct contact place (place type 2).

Several locational methods can be used in determining the repulsion or attraction between twro types of plants or points. The most effective method according to Upton and Fingleton ${ }^{24)}$ (1985) is based on nearest neighbor distances.

One of the most effective nearest neighbor distance methods mentioned by Upton and Fingleton ${ }^{251}$ (1985) is paired point-place distances. The logic behind this method is that if there is a repulsion between the two types of places, then if a certain randomly chosen points is near to place type 1 , it must be far to place type 2 and vice versa. Therefore by generating sufficient random points within the study area and calculating the paired distances $(\mathrm{x}, \mathrm{y})$ from the random point to the nearest place type $1(\mathrm{x})$ and place type $2(y)$, we can derive some kind of correlation measures. Upton and Fingleton ${ }^{26)}$ suggested that we rank $\mathrm{x}$ and $\mathrm{y}$ separately and use Spearman's paired rank correlation measure (see Siegel ${ }^{27}$ (1956)).

Table 5 shows the result of paired point-place distance analysis in terms of Spearman's r. As a conclusion it can be seen that there are significant attraction between the two types of places in all of the five cities in this study.

The conclusion of table 5 means that the places that are segregated in the mind of our respondents are actually existed in similar space. The respondents seem to be able to differentiate the places among the 
Table 5 Table of Spearman's paired rank correlation of nearest neighbor distance of random points to place type 1 and place type 2 .

\begin{tabular}{|c|c|c|}
\hline c1 ty & $\begin{array}{l}\text { Spearman's r of } \\
\text { paired rank of nearest } \\
\text { nelghbor distances }\end{array}$ & $z$-values \\
\hline Nagaoka & 0.49 & 5.16 \\
\hline Toy ama & 0.49 & 10.64 \\
\hline Joetsu & 0.49 & 4.41 \\
\hline Murakam1 & 0.47 & 5.18 \\
\hline ShIbata & 0.48 & 4.81 \\
\hline
\end{tabular}

Table 6 Table of the significant nearest neighbor distances $\left(\mathrm{v}^{*}\right)$.

Nagaoka
Toyama

spatially undifferentiated places. Before we discuss this conclusion further, let us first assess the distance where this spatial attraction exists.

By comparing the cumulative distributions (F) of distance from random points to the nearest place type 1 (type 2 ) to the cumulative distribution $(G)$ of the distance from place type 1(or type 2 ) to the nearest place type 2 (or type 1 ), we can assess the distance where the attraction shown on table 5 exists $^{28)}$.

Figure 2 shows the distribution of $F$ and $G$ for the five cities in the study. The significant difference between the $F$ and $G$ distribution for the five cities in the study further supports the previous conclusion about the spatial attraction between the two types of places.

The significant inter-place nearest neighbor distance $\mathrm{V}^{*}$ can be found by pin-pointing the nearest neighbor distance (v) where the difference between $G(v)$ and $F(v)$ is maximum (Figure 2).

From table 6 we can see that Joetsu and Nagaoka have the largest number of significant inter-place nearest neighbor distance. This result can be explained if we look at the pattern of spatial development in the five cities. The relatively larger dominant nearest neighbor distance in Joetsu and Nagaoka city represents the decentralization of direct contact places (places type 1). For Joetsu city this phenomena can be seen from the development of new urban center (The city hall, Region Plaza, Jusco and their surrounding), away from the old urban center near Takada or Naoetsu rail station. This may be due to the effort of the government to bridge the spatial gap between Naoetsu and Takada which were once separate cities.

Similar phenomena can also be seen in Nagaoka city where the new center of place type 1 begin to develop on the other side of Shinano river.

As a discussion, it can be argued that the analysis of nearest distance neighbor which is based on Cartesian distance is unrealistic. If we would have used the real route distance between two places, there would be a spatial and quantitative dualism in the psychological map of our respondents. This problem can be considered as one of the most serious critics which can be put forward in terms of the locational methods that were proposed by Upton and Fingleton ${ }^{291}$ (1985). However if we look at the significant nearest neighbor distance shown on table 6 , it is on the average similar to the walking distance of human being mentioned by some researcher such as Tonuma ${ }^{301}$. (1978). Therefore it is less constrained by vehicular routes and streets. Thus the real physical distance to a certain degree is similar to the Cartesian distance we used in this study.

The similarity between walking distance mentioned by Tonuma ${ }^{311}$ (1978) and the average significant nearest neighbor distance $\mathrm{v}^{*}$ shown on table 6 also shows that the physical structures of former castle town still influence the psychological map of the cities.

As city develops, it begins to develop new zones to accommodate the needs of its inhabitants. 


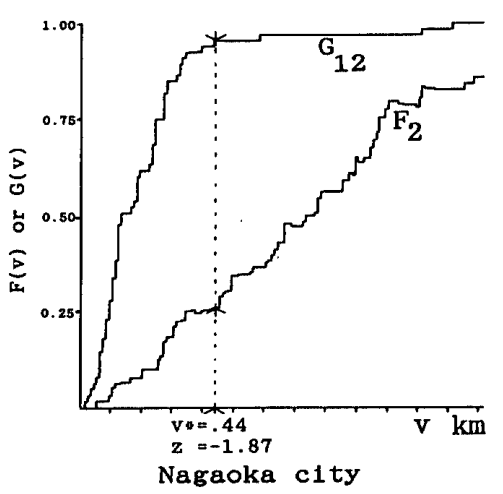

(a)

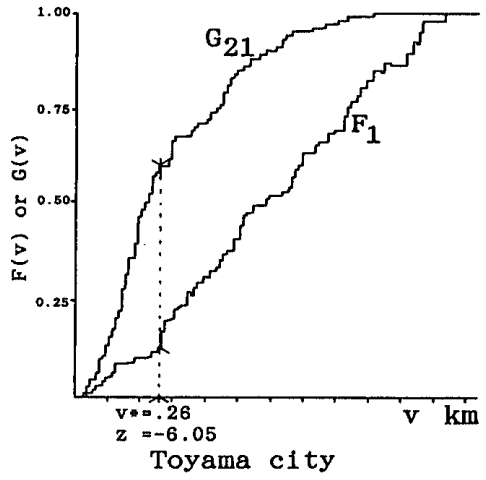

(d)

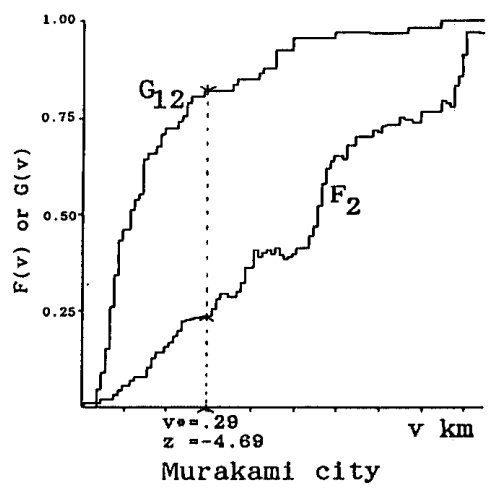

(g)

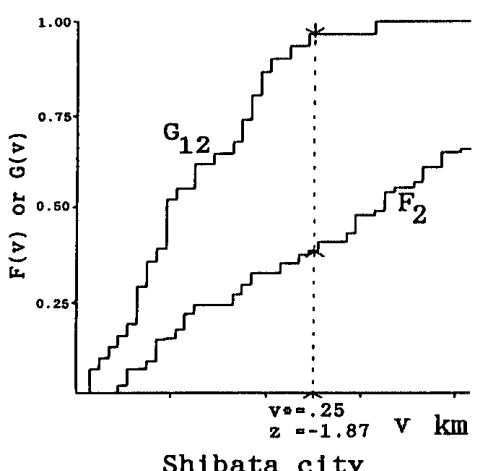

(i)

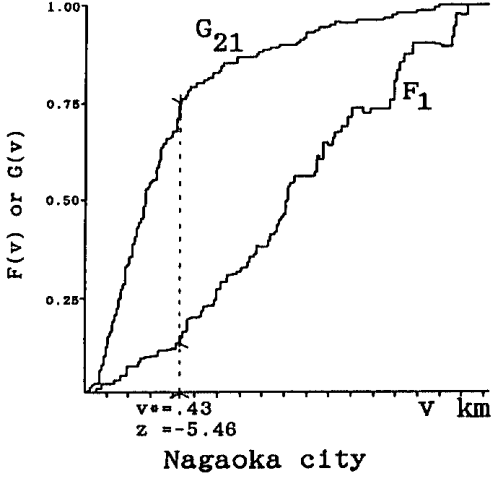

(b)

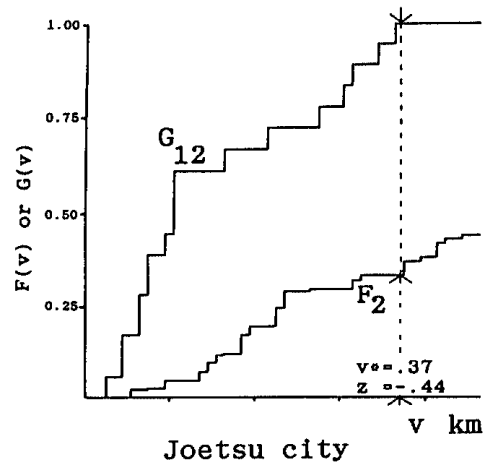

(e)

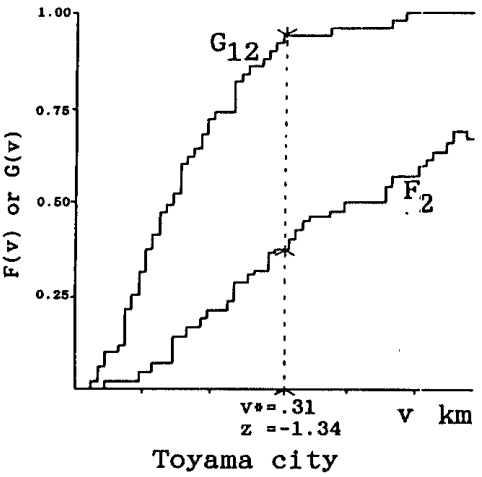

(c)

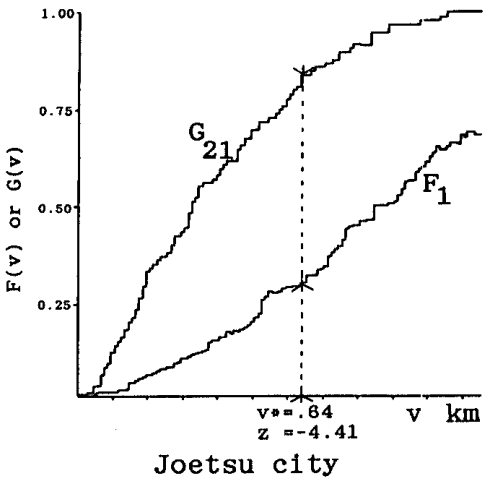

(f)

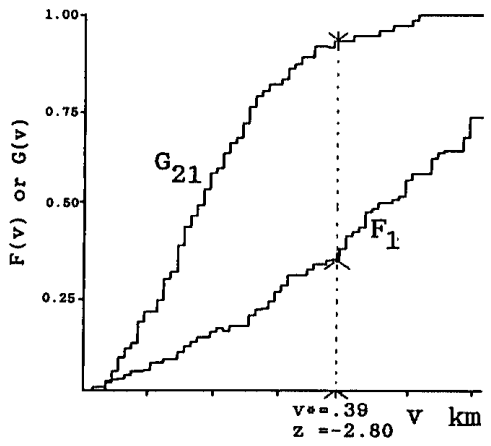

Murakami city

(h)

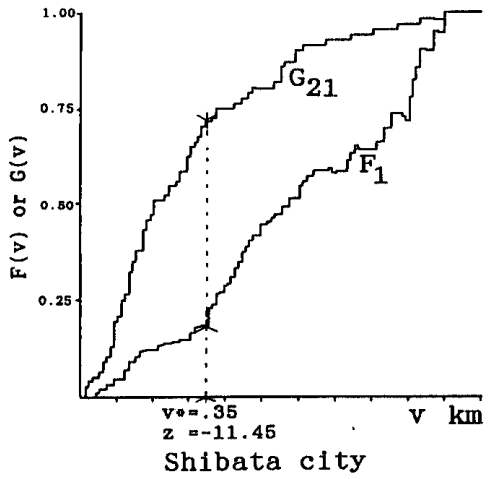

(j)

Figure 2 The cumulative distribution of distance of random point to its nearest place type $j(F j)$, and the cumulative distribution of distance of place type $i$ to its nearest place type $j(G i j)$, where $i=1,2$ and $j=1$, 2. $z$ is the standard value of $v, z$ is also known as the Mann-Whitney two sample rank sum test statistics, or as Wilcoxson test statistics. 


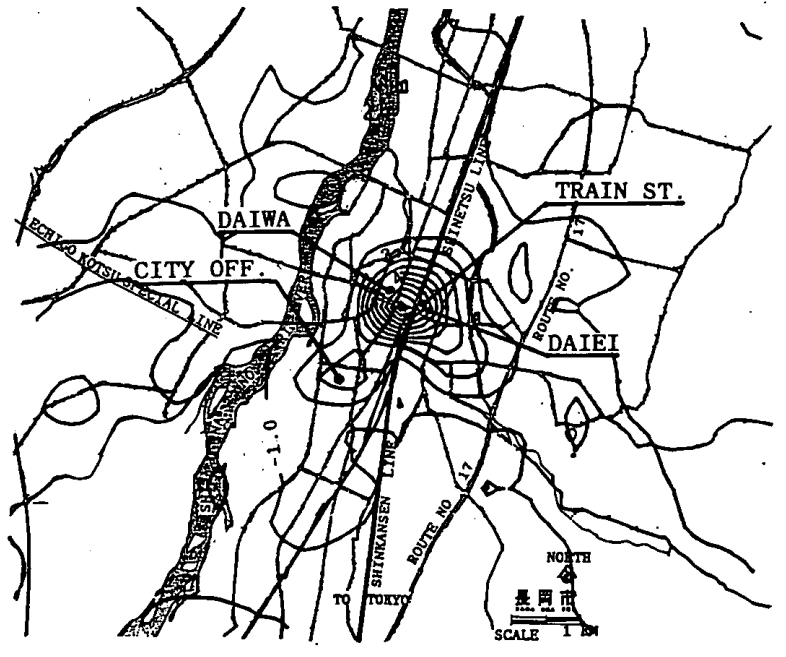

Figure 3. a. Contour map of direct component score of Nagaoka city.

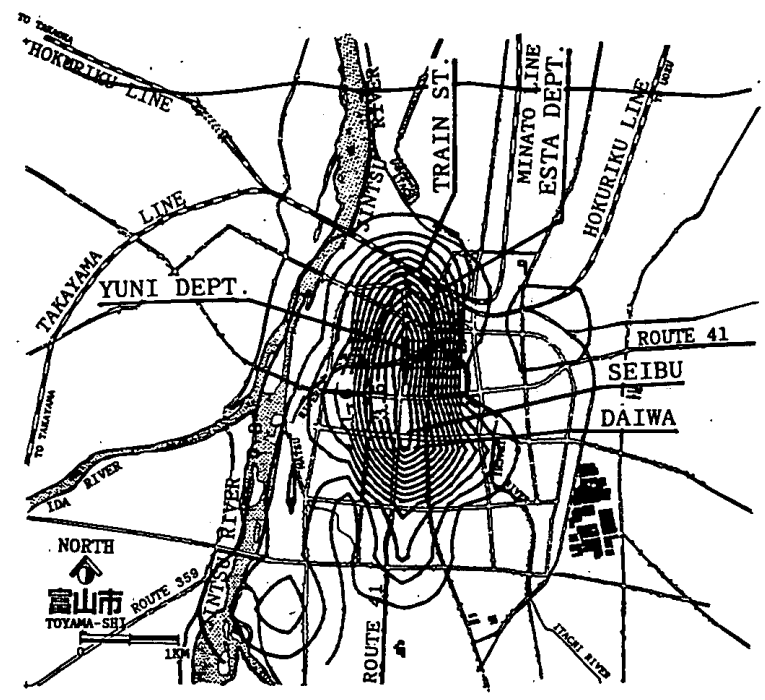

Figure 3.c. Contour map of direct component score of Toyama city.

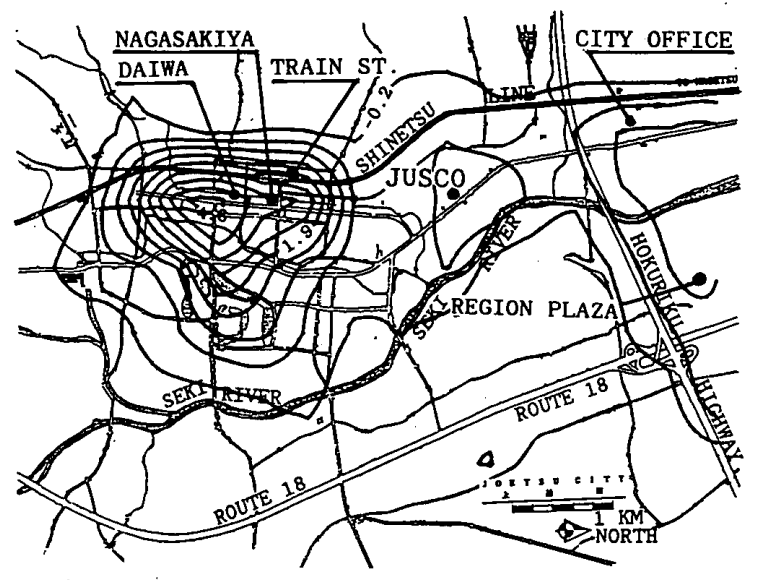

Figure 3. e. Contour map of direct component score of Joetsu city.

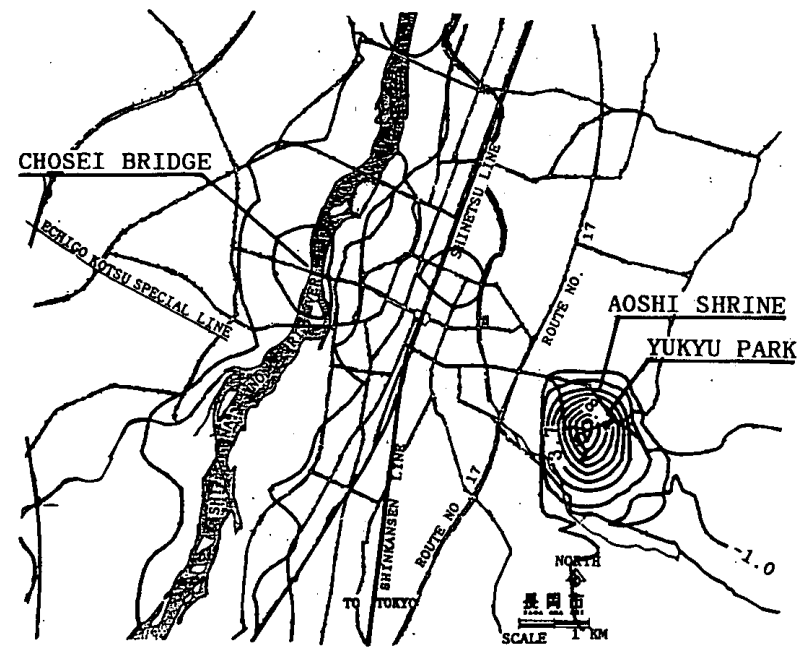

Figure 3. b. Contour map of in-direct component score of Nagaoka city.

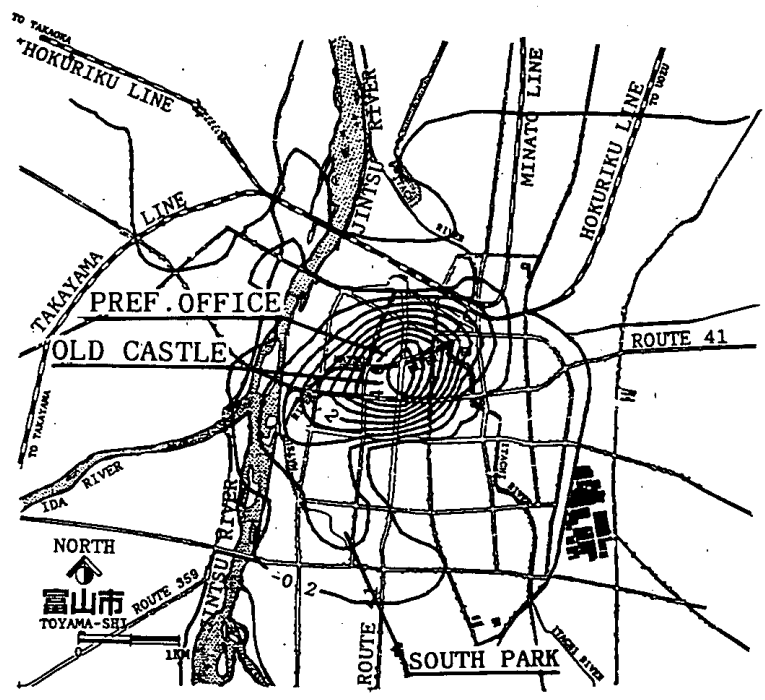

Figure 3. d. Contour map of in-direct component score of Toyama city.

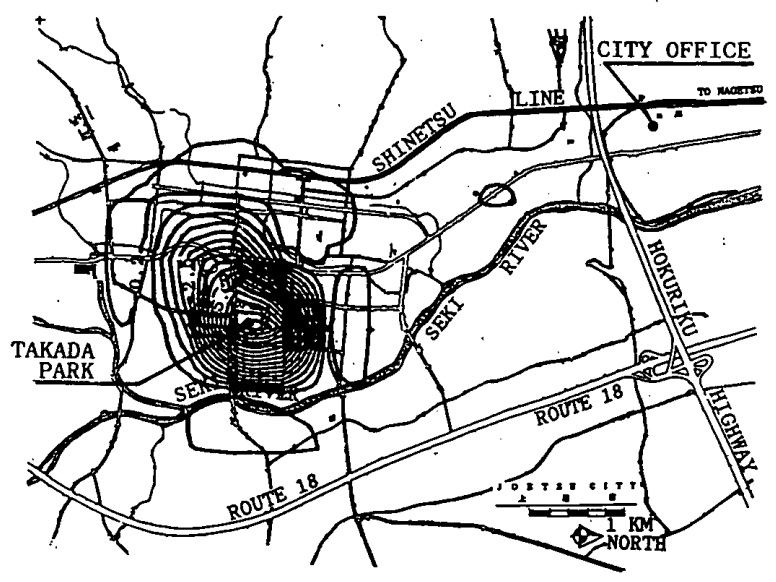

Figure 3. f. Contour map of in-direct component score of Joetsu city.

Therefore it tends to spread. The spreading phenomena not only tends to segregate the city spatially, but also increase the significant nearest neighbor distance. In the scope of the study area of the five cities, this spatial segregation has not yet followed the psychological dualism discussed on 3.1. Maybe 


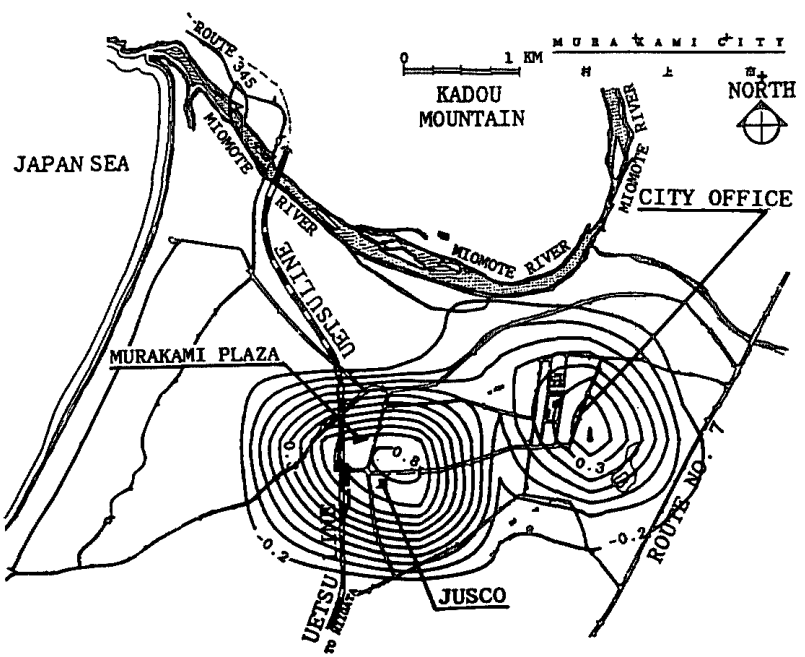

Figure 3. g. Contour map of direct component score of Murakami city.

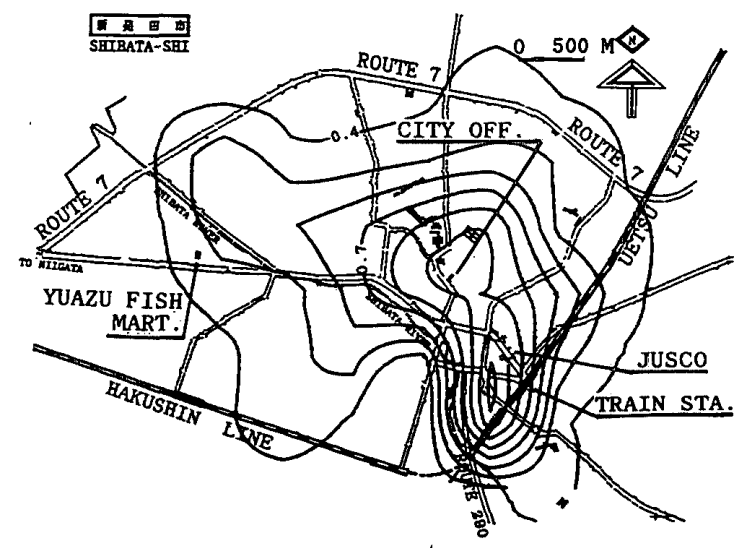

Figure 3.i. Contour map of direct component score of Shibata city.

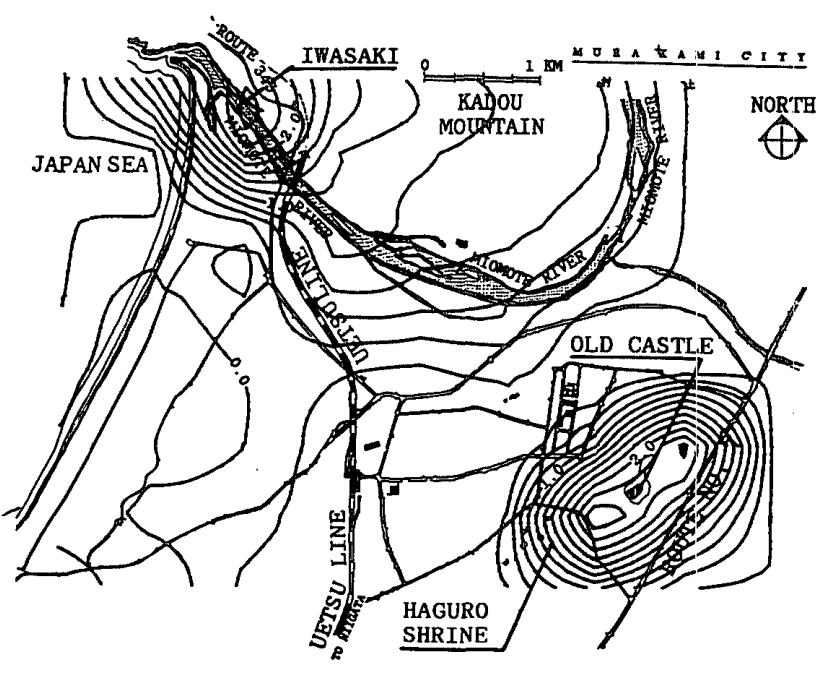

Figure 3.h. Contour map of in-direct component score of Murakami city.

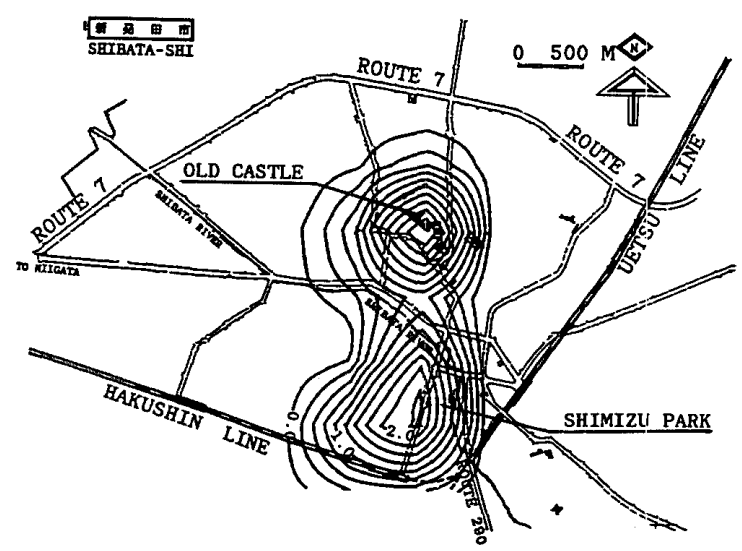

Figure 3. j. Contour map of in-direct component score of Shibata city.

it is due to its castle town past which are known to have narrower street and land plots (Fujioka ${ }^{32}$, 1980). Nevertheless the increase of the dominant nearest neighbor distance to some degree has been observed in Joetsu and Nagaoka city. It seems that for the five cities, their psychological nature is more stable than their spatial characteristics.

\section{3 Ecological Analysis}

By analyzing our data ecologically, we hope to bring out the combined influence of spatial and non quantitative data. The variable score of each machi is the sum of variable score of places within each machi. In other words it is a quadrat counts of variable score of places. Except the quadrat is machi unit which is more natural than the fixed size quadrats. The five variable score of machi were then analyzed by using principal component analysis. As a result, two components similar in its variable explanation to the dual components of section 3.1 were extracted. The contour maps of the components scores are shown on Figure 3.

Again by looking at table 7 we can understand the difference that exists among the cities. We can see that the higher the percentage of error the less is the separation between the peak of score map of the two components. For instance in Nagaoka, the percentage of error of the reproduce correlation matrix larger than 0.05 is relatively the smallest $(30 \%)$. In Nagaoka city, the peak of indirect component which is located near Yukyusan park is totally detached from the peak of direct component score map near the rail station. The place where the direct component peak exists is not the peak of indirect component map. As we can see from score maps of Nagaoka city shown on figure 3. a., and 3. b. the segregation is due to 
decentralizing developments mentioned on 3.2. Shibata also has a small percentage of error of the reproduced correlation matrix. But since the segregation in Shibata does not involve new spread of development (fig. 3. i. ) the cause of this segregation is considered as different to that of Nagaoka city. In other hand, Toyama which has the highest percentage of error of the reproduced correlation matrix (70\%) that segregation phenomena can not clearly be seen. This phenomena may be due to the fact that the concentration of the two types of place is located at the old machi.

Locationally, the logic behind ecological analysis is similar to quadrat count analysis. Therefore if large number of machis have similar variable scores of place type 1 and of place type 2 , then we can conclude that there is an attraction between both types of places.

If for a city the percentage of error of the reproduce correlation matrix which is above 0.05 is large, then we can conclude that in the city there is an attraction between the two types of places. Thus in this section we can conclude that Toyama city has the highest inter-machi type spatial attraction while Shibata and Nagaoka has the smallest inter-machi type spatial attraction.

\section{Conclusion}

The conclusion of this study can be summarized as the followings:

(a) The method that were used in this study were effective in bringing out the repetition of pattern or principle from the psychological maps of the five cities that were formed by using topophilic variables.

(b) In psychological space, the patterns that were extracted from the five topophilic variables in terms of quantitative data by using non-locational method consist of two components. The first is what were named as direct contact component, while the second component as in-direct contact component. This dual components were considered as one of the characteristics of city with significant history such as former castle town.

(c) In terms of the components structures, the differences that exist among the five cities represent the transformation of place type 2 that were subjected to the development of place type 1 . Thus, the transformation does effect topophilic structure of the five cities in the study.

(d) Locationally, for the five cities in the study; the places that were psychologically differentiated into direct and in-direct contact places (place type 1 and type 2), were not differentiated in physical space. The significant nearest neighbor distance is similar to walking distance which indicates that the topophilic structure of the cities is influenced by the shape of their castle town past.

(e) In terms of physical space, the differences that exist among the five cities represent the decentralized development of places type 1 . Thus it can be concluded that the topophilic structure of the cities is affected by modern developments.

(f) The difference between the differentiated psychological space and the unified physical space represents the difference between perception and attitudes. While perception can be easily influenced by physical factors, attitudes such as topophilia is less influenced by physical factors.

Finally, we can suggest that even though our study have only been used to shed the characteristics of five former castle town that were located in the mid-northern part of Japan, the method and result can also be used to open the door to other studies about topophilia in other cities in general. Thus we hope this study can help bring further light to future study of topophilia.

\section{Acknowledgment}

We would like to thank Mr. Okuda and Mr. Sakai of Niigata University City Planning Laboratory for 
their assistance. We would also like to thank the people of Shibata, Murakami, Joetsu, Nagaoka, and Toyama City for their cooperation. All has been very kind and helpful to us in finishing this paper.

\section{References}

1) Charles Jencks, The Language of Post Modern Architecture, 4th ed., (New York: Rizzoli), pp. 5 37, 1984.

2) Randy Hester, "Subconscious Landscape of The Heart," Places, Vol.2, No. 3, pp. 10 22, 1981.

3) Yi-Fu Tuan, Topophilia, A Study of Environmental Perception, Attitudes; And Values, (New Jersey : Prentice-Hall, Inc. ), pp. $92-128,1974$.

4) Ibid., p. 4 .

5) Jon Lang, "Symbolic aesthetics in architecture: toward a research agenda, "in Jack L. Nasar edition of Environmental Aesthetics, Theory, Research, and Applications, (New York: Cambridge University Press), pp. 11 26, 1988.

6) Donald Appleyard, "Why Buildings Are Known. A Predictive Tool For Architects and Planners," Environmental and Behavior (December), pp. 131 156, 1969.

7) Gary W. Evans, Catherine Smith and Kathy Pezdek, "Cognitive Maps and Urban Form," APA Journal (Spring), pp. 232 244, 1982.

8) Yi-Fu Tuan, p. 3.

9) Peter Gould and Rodney White, Mental Maps (Baltimore, Penguin, 1974).

10) Ibid.

11) Stanley Milgram, Judith Greenwald, Suzanne Kessler, Wendy McKenna, and Judith Waters, “A Psychological Map of New York City," American Scientist, Vol.6, p. 194, 1972.

12) Ibid., pp. 194 201

13) Ibid.

14) Yi-Fu Tuan, pp. 92 128.

15) Ibid.

16) Ibid. pp. 99 100.

17) Ibid. pp. 93 $\sim 95$.

18) Ibid. pp. $100 \sim 102$.

19) Ibid. pp. 95 99.

20) Agus Budi Purnomo Ishak, The Study On Environmental Image By Using Mental Map and Socio-Economic Map, (unpublish master's thesis, University of Niigata), p. 15, 1988.

21) Tadahiko Higuchi, Tamagawa Hidenori, Agus Budi Purnomo Ishak, "A Study on the optimum mesh size for continuous variables- an example by using a mental map," Papers on City Planning, No. 23 (The City Planning Institute of Japan), pp. 37 $\sim 42,1988$.

22) Peter Gould and Rodney White.

23) Stanley Milgram, Judith Greenwald, Suzanne Kessler, Wendy McKenna, and Judith Waters.

24) Graham J. G. Upton and Bernard Fingleton, Spatial Data Analysis by Example. Vol. I, Point Pattern and Quantitative Data (New York), pp. 242 252, 1985.

25) Ibid.

26) Ibid., p. 251.

27) S. Siegel, Nonparametric Statistics For Behavioral Science (McGraw-Hill, 1956).

28) Graham J.G. Upton and Bernard Fingleton, pp. 246 250.

29) Ibid., pp. 242 252.

30) K. Tonuma, Ningen Shakudo Ron (Tokyo, Shokokusha), pp. 147 153 (in Japanese), 1978.

31) Ibid.

32) K. Fujioka, "The Changing Face of Japanese Jokamachi (Castle Towns) Since Meiji Period", on Geography of Japan, edited by The Association of Japanese Geographers (Tokyo, Teikokushoin), pp. 196 160, 1980.

(Manuscript received September 10, 1990 ; Paper Accepted May 1, 1991) 


\section{和文要約}

住民に好まれる都市を開発するためには，都市の中の どこが,あるいはどのようなところが愛されているのか, またはよく知られているのかを知る必要がある。このよ うなことに関連して，チュアン（1974）は，「トポフィ リア」(場所愛)という概念を用い，人間の環境に対す る愛着を示している。本論文は，この概念を日本の五つ の旧城下町という具体的な場において理解しようとする 試みである。ただし，アップルヤード（1969）らが行っ たように知覚という概念でトポフィリアをとらえるので はなく，環境に対する態度という観点から，ミルグラム (1972)）が提起するにとよ゙まった環境認知の根源を実証 的に抽出し, 都市間比較によりその意味をより明らかに しようとするものである。

方法としては，各都市において，下記（2）の5つの 項目についてアンケート調查を行い，因子分析により主 要 2 因子を抽出，その因子構造および空間分布特性を分 析することにより，各都市のトポフィリアを比較した。 本研究の結論は次のようにまとめることができる。

（1）本研究で用いた方法は，5つの都市のトポフィリ アにかかわる心理学的地図を比較考察するのに有効で あった。

（2）分析に用いた 5 つの変数は，因子分析により，2 つの因子にまとめられた。すなわち,「頻繁に訪れる場所」 と「よく通る道に隣接する場所」の 2 つの変数に強く関
連する直接接触因子，および「美しい場所」と「保護す べき場所」に強く関連する間接接触因子であり，この二 元性は, 旧城下町のような歴史のある都市の特徴と考え られる。

（3） 因子構造からみて，5つの都市間の差異は, 間接 接触的場所（例えば，旧城跡なごの歴史的・文化的特色 のある空間）が直接接触的場所（例えば，日常買物をす る商店街など）の発展によってどのように変容している， か，ということに梁くかかわっているということが見い だせた。

（4）5つの都市においては，物理的には同じあるいは

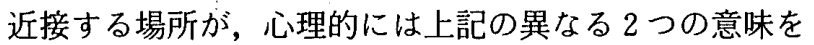
持った場所になっていることが多かった。これも, 歴史 性のある旧城下町の特徴と考えられる。

（5）物理的空間という観点からみると，5つの都市間 の差異は，直接接触的場所が，近代的開発に影響を受け 分散化される傾向にある度合いに求められることが示さ れた。

以上, 知覚が, 物理的なファクターに影響されやすいの に対して,トポフィリアのような態度は, 物理的なファ クターに影響されにくいことが分かった。このことより， 知覚でなく態度に着目してトポフィリアを研究するとい う方向性は有効であったといえよう。 